\title{
Growth, biomass and lipid productivity of a newly isolated tropical marine diatom, Skeletonema sp. UHO29, under different light intensities
}

\author{
INDRAYANI INDRAYANI ${ }^{1, \bullet}$, HASLIANTI HASLIANTI ${ }^{2}$, ASMARIANI ASMARIANI ${ }^{3}$ \\ WELLEM H. MUSKITA ${ }^{4}$, MUIS BALUBI ${ }^{4}$ \\ ${ }^{1}$ Department of Aquatic Resources Management, Faculty of Fisheries and Marine Science, Universitas Halu Oleo. Jl. HEA. Mokodompit, Kampus Hijau \\ Bumi Tridharma, Anduonohu, Kendari 93232, Southeast Sulawesi, Indonesia. `email: indrayani_tajudin@yahoo.com.au \\ ${ }^{2}$ Department of Fisheries Products Technology, Faculty of Fisheries and Marine Science, Universitas Halu Oleo. Jl. HEA. Mokodompit, Kampus Hijau \\ Bumi Tridharma, Anduonohu, Kendari 93232, Southeast Sulawesi, Indonesia \\ ${ }^{3}$ Fisheries Laboratory, Faculty of Fisheries and Marine Science, Universitas Halu Oleo, Jl. HEA. Mokodompit, Kampus Hijau Bumi Tridharma, \\ Anduonohu, Kendari 93232, Southeast Sulawesi, Indonesia \\ ${ }^{4}$ Department of Aquaculture, Faculty of Fisheries and Marine Science, Universitas Oleo. J1. HEA. Mokodompit, Kampus Hijau Bumi Tridharma, \\ Anduonohu, Kendari 93232, Southeast Sulawesi, Indonesia
}

Manuscript received: 16 January 2020. Revision accepted: 19 March 2020.

\begin{abstract}
Indrayani I, Haslianti H, Asmariani A, Muskita WH, Balubi M. 2020. Growth, biomass and lipid productivity of a newly isolated tropical marine diatom, Skeletonema sp. UHO29, under different light intensities. Biodiversitas 21: 1498-1503. Light is one of the important factors affecting growth and biochemical composition of microalgae. The aim of this study was to determine growth, biomass and lipid productivity of a newly isolated marine diatom, Skeletonema sp.UHO29 under different light intensities. The Skeletonema sp. was cultured in $300 \mathrm{~mL}$ conical flasks containing $150 \mathrm{~mL}$ of $\mathrm{f} / 2$ medium under three different light intensities $(28,60$ and $110 \mu \mathrm{mol}$ photons $\mathrm{m}^{-2} \mathrm{~s}^{-1}$ ) with three replications. The cultures were incubated under ambient room temperatures, and a cycle of 12 hours light and 12 hours dark, in batch modes for two weeks. The results showed that the highest specific growth rate $\left(0.56 \mathrm{~d}^{-1}\right)$ was achieved at the highest light intensity $\left(110 \mu \mathrm{mol}\right.$ photons $\left.\mathrm{m}^{-2} \mathrm{~s}^{-1}\right)$ and the lowest $\left(0.11 \mathrm{~d}^{-1}\right)$ was obtained at the lowest light intensity $(28$ $\mu \mathrm{mol}$ photons $\left.\mathrm{m}^{-2} \mathrm{~s}^{-1}\right)$. The highest biomass yield $\left(0.62 \mathrm{~g} \mathrm{~L}^{-1}\right)$ and biomass productivity $\left(0.34 \mathrm{~g} \mathrm{~L}^{-1} \mathrm{~d}^{-1}\right)$ was achieved at the highest light intensity. However, the highest lipid yield $\left(0.175 \mathrm{~g} \mathrm{~L}^{-1}\right)$, lipid content $(28.78 \%$ ash-free dry weight $)$ and lipid productivity $\left(0.067 \mathrm{~g} \mathrm{~L}^{-1} \mathrm{~d}^{-}\right.$ ${ }^{1}$ ) were achieved at medium light intensity. The alga prefers high light intensity for higher growth rate and biomass productivity but it produces more lipids at medium light intensity. This study indicated that the Skeletonema sp.UHO29 is a potential species for outdoor mass cultivation and is a promising microalgal strain for use as a biodiesel feedstock due to its high growth rate, high biomass and lipid productivity.
\end{abstract}

Keywords: Growth, light intensity, lipid productivity, Skeletonema sp.UHO29

\section{INTRODUCTION}

Microalgae have been suggested as a potential biodiesel feedstock due to their ability to produce a high quantity of lipids that can be converted to biodiesel (Chisti 2007; Hu et al. 2008; Mata et al. 2010; Parmar et al. 2011). In comparison with terrestrial crops, microalgae produce higher yield of lipids. Depending on the lipid content, microalgae can produce about 58,700 - 136,900 L oil ha year ${ }^{-1}$ which is much greater than the yields obtained for crops like soybean $\left(636 \mathrm{~L}\right.$ oil ha ${ }^{-1}$ year $\left.^{-1}\right)$, jatropha $(741 \mathrm{~L}$ oil ha ${ }^{-1}$ year $\left.^{-1}\right)$, canola ( $974 \mathrm{~L}_{\text {oil ha }}$ year $^{-1}$ ) and palm oil (5366 L oil ha' year $^{-1}$ ) (Ahmad et al. 2011). Furthermore, microalgae are potentially more sustainable to grow for lipid production than conventional crops due to the facts that microalgae can be grown on non-arable land and can use seawater which implies that they will not compete with food crops for scarce agricultural habitats and for limited sources of freshwater (Borowitzka and Moheimani 2013). In addition, they can also utilize industrial flue gasses as a carbon source (Chisti 2007).

In relation to microalgal lipid production, diatoms (Bacillariophyceae) are particularly interesting due to their well-known capability to accumulate high amount of lipids (Rodolfi et al. 2009; Khatoon et al. 2010; Chen 2012). Neutral lipids (mainly triacylglycerols (TAGs)) accumulate in diatoms in their late stationary phase ( $\mathrm{Hu}$ et al. 2008). This is because TAGs are the main storage products in the diatom cells when photosynthetic assimilation occurs during the time when cell division is arrested due to nutrient starvation (Popovich et al. 2012). The TAG accumulation in diatoms can reach an excess of $60 \%$ of the total lipid content (Chen 2012).

Growth and lipid production in microalgae are speciesspecific and are influenced by environmental/culture conditions including light intensity (Pal et al. 2011; AlQasmi et al. 2012; Sforza et al. 2014; Wang et al. 2018). Light is important as the energy source that drives photosynthesis in microalgae (Masojidek et al. 2013). Both the quality and the quantity of light affect the productivity of photosynthetic cultures (Pulz and Scheinbenbogen 1998). However, too much light intensity may result in reduced productivity due to photo-inhibition and photooxidation (Borowitzka 2016), while low light intensity will become growth-limiting (Pal et al. 2013). 
Skeletonema sp.UHO29 is a diatom species recently isolated from a coastal area in Kendari, Southeast Sulawesi, Indonesia. As a newly isolated species, there is no information available regarding the factors that limit its growth; especially variation in light intensity. Therefore, the aim of this study was to determine the effect of different light intensities on the growth, biomass and lipid productivity of the Skeletonema sp.UHO29.

\section{MATERIALS AND METHODS}

\section{Microalgal species}

The Skeletonema sp.UHO29 was isolated from Nambo Beach, Southeast Sulawesi, Indonesia in June 2017 (Indrayani et al. 2018). The alga was isolated using the enrichment method followed by agar plating technique in 1\% agar (Andersen and Kawachi 2005) in Guillard's f/2 medium (Guillard and Ryther 1962). Pure colonies were obtained after repeated plating on agar medium. The strain is non-axenic and is maintained in the Microalgae Culture Collection at the Faculty of Fisheries and Marine Science, Halu Oleo University, Kendari, Southeast Sulawesi, Indonesia.

\section{Culture condition}

For the experiment, the alga was cultured in $300 \mathrm{~mL}$ Erlenmeyer flasks containing $150 \mathrm{~mL}$ of $\mathrm{f} / 2+\mathrm{Si}$ medium at $3.2 \%$ salinity. The cultures were illuminated with white fluorescent lamps at three different light intensities $(28,60$ and $110 \mu \mathrm{mol}$ photons $\mathrm{s}^{-2} \mathrm{~s}^{-1}$ ) with a $12 \mathrm{~h}$ light and $12 \mathrm{~h}$ dark cycle under ambient room temperatures. There were three flask cultures for each treatment. The cultures were aerated to facilitate mixing and were run in a batch mode for two weeks.

\section{Analytical methods}

The growth of the cultures was monitored by counting the cell numbers every two days using a Neubauer hemocytometer (Moheimani et al. 2013).

The specific growth rate $\left(\mathrm{d}^{-1}\right)$ was calculated using the following equation :

$$
\mathrm{SGR}=\ln \left(\mathrm{N}_{2} / \mathrm{N}_{1}\right) /\left(\mathrm{t}_{2}-\mathrm{t}_{1}\right)
$$

Where $N_{1}$ and $N_{2}$ are the cell density at time $\left(t_{1}\right)$ and 2 $\left(t_{2}\right)$ within the exponential phase.

For Dry Weight (DW) and Ash-free Dry Weight (AFDW) determination, five $\mathrm{mL}$ of the culture was filtered through pre-weighted and pre-combusted Whatman GF/C, $25 \mathrm{~mm}$ filter paper using Millipore filter apparatus. The filter papers were removed from the filter apparatus, folded and patted dry with a paper towel before being dried in an oven at $75^{\circ} \mathrm{C}$ for 5 hours. DW was calculated by the following equation (Indrayani et al. 2019; 2020):

Dry Weight $\left(\mathrm{g} \mathrm{L}^{-1}\right)=$ (weight of filter plus algae $)$ (weight of filter)

The filters were then transferred to a furnace for ashing at $450^{\circ} \mathrm{C}$ for 5 hours. Organic dry weight (Ash-free dry weight) was then calculated by the following equation (Indrayani et al. 2019; 2020):

\section{AFDW $\left(\mathrm{g} \mathrm{L}^{-1}\right)=$ Dry weight - weight of ash}

Biomass productivity was calculated using the equation below (Moheimani et al. 2013):

\section{Biomass Productivity $\left(\mathrm{g} \mathrm{L}^{-1} \mathrm{~d}^{-1}\right)=$ SGR x AFDW}

For lipid determination, total lipid was extracted using the method of Bligh and Dyer (1959) as modified by Kates and Volcani (1966), adapted by Mercz (1994). Briefly, five $\mathrm{mL}$ of culture was filtered through Whatman GF/C, $25 \mathrm{~mm}$ filter paper secured in Milliopore filter apparatus. The filters containing cells were inserted in a small test tube and then crushed with a glass rode until a smooth green paste of about $0.5 \mathrm{~mL}$ was obtained. $1 \mathrm{~mL}$ of the solvent mixture (methanol: chloroform: deionized (DI) water in the ratio of 2: $1: 0.8 \mathrm{v} / \mathrm{v} / \mathrm{v}$ ) was added into the tubes, homogenized well and then transferred into a tube with screw cap. Another 1 $\mathrm{mL}$ of the solvent mixture was added into the glass tube to wash and clean all the remaining cell debris and then transferred into the tubes. $3.7 \mathrm{~mL}$ of the solvent mixture was added into the tubes, tightly screwed before centrifugation at $3000 \mathrm{rpm}$ for 20 minutes. After centrifugation, the supernatant was transferred to a $20 \mathrm{~mL}$ glass tube with screw cap. For the second extraction, 5.7 $\mathrm{mL}$ of the solvent mixture was added to the pellet in the centrifuge tube, vortexed, then centrifuged again at 3000 $\mathrm{rpm}$ for 20 minutes. The supernatant was combined together in the $20 \mathrm{~mL}$ glass tube. Three $\mathrm{mL}$ of DI water and $3 \mathrm{~mL}$ of chloroform were added to the $20 \mathrm{~mL}$ tubes and mixed well by vortexing. The samples were then stored in the fridge undisturbed for 24 hours for complete separation. After incubation, two phases were observed in the tubes, the top layer containing methanol and water and the bottom layer containing chloroform and the lipids. The upper layer was removed with a very fine Pasteur pipette. The vials were then put under a stream of pure $\mathrm{N}_{2}$ gas, with heating plates at $40^{\circ} \mathrm{C}$ until complete dryness. After complete evaporation, the vials containing lipids were carefully weighed using an analytical balance. Weight of lipids was calculated by subtracting the weight of the vials from the weight of the vials containing lipids.

Lipid productivity was calculated using the following equation (Moheimani et al. 2013):

$$
\text { Lipid Productivity }\left(\mathrm{g} \mathrm{L}^{-1} \mathrm{~d}^{-1}\right)=\text { SGR } x \text { Lipid Yield }
$$

\section{Statistical analysis}

Significant differences between treatments were analyzed with a one-way analysis of variance (One-Way ANOVA). A pairwise multiple comparison procedure (Holm-Sidak Method) was then used to precisely test differences between light treatments. All statistical analyses were performed using the Sigma-Plot 14 package (Systat Software Inc., USA). 


\section{RESULTS AND DISCUSSION}

\section{Results}

The alga used in this study was recently isolated from a coastal area in Kendari, Southeast Sulawesi, Indonesia and identified as Skeletonema sp. It is a chain-forming planktonic diatom with a cell size ranging from $4-6 \mu \mathrm{m}$ in length (Figure 1).

The growth of the Skeletonema sp. under different light intensities during a two week culture period can be seen in Figure 2. In the first two days, all the cultures showed slow growth indicating that the cells were in the adaptation period (lag phase). From day 2 to 4 , all the cultures entered the exponential growth phase during which the cells multiply fast. From day 4 onwards, the cultures entered the early stationary phase. The highest cell density $\left(383 \times 10^{4}\right.$ cells $\mathrm{mL}^{-1}$ ) was achieved at the highest light intensity whereas the lowest cell density $\left(167 \times 10^{4}\right.$ cells $\left.\mathrm{mL}^{-1}\right)$ was obtained at the lowest light intensity (Figure 2).

The specific growth rate (SGR) of the Skeletonema sp. was affected by the light intensity tested (One Way ANOVA, $\mathrm{p}=0.002$ ). The SGR of the Skeletonema $\mathrm{sp}$. at low, medium and high light intensity ranged from 0.109$0.278 \mathrm{~d}^{-1}, 0.434-0.485 \mathrm{~d}^{-1}$, and 0.435-0.555 $\mathrm{d}^{-1}$, respectively. Significant differences were observed between SGR at high light intensity and low light intensity (Holm-Sidak method, $\mathrm{p}=0.004$ ) and between medium light and low light intensity (Holm-Sidak method, $\mathrm{p}=0.004$ ). However, no significant difference was observed between high light and medium light intensity (Holm-Sidak method, $\mathrm{p}=0.605$ ) (Figure 3 ).
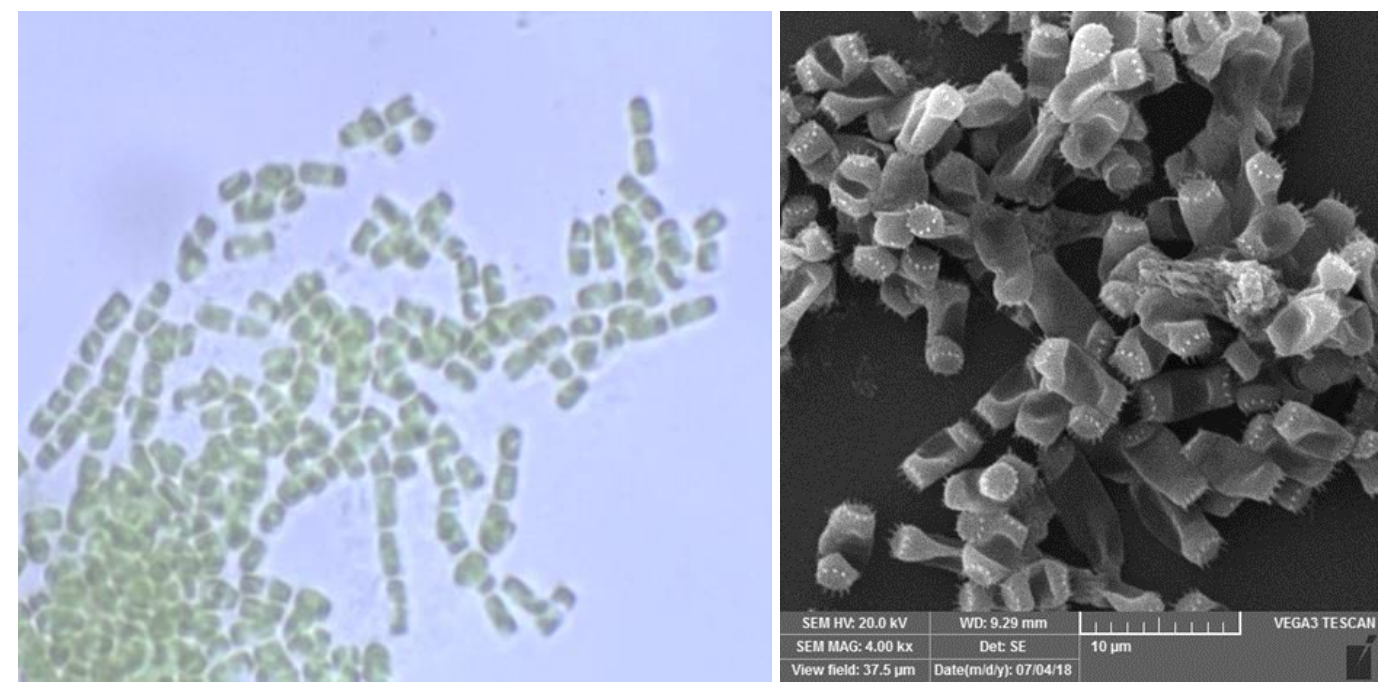

Figure 1. Images of Skeletonema sp.UHO29 under light microscope at 100x magnification (left) and scanning electron microscope at 4000x magnification (right)

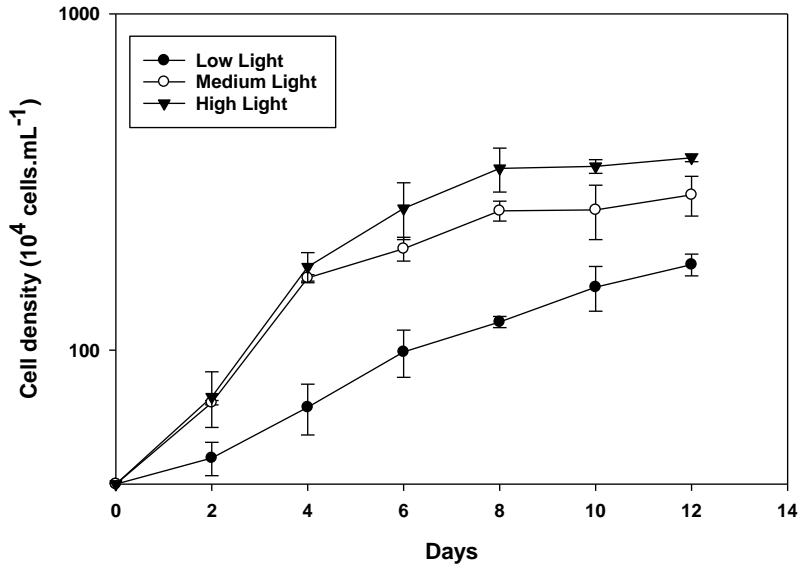

Figure 2. The growth curve of the Skeletonema sp. under different light intensities; low light intensity $\left(28 \mu \mathrm{mol}\right.$ photons $\mathrm{m}^{-}$ $\left.{ }^{2} \mathrm{~s}^{-1}\right)$, medium light intensity $\left(60 \mu \mathrm{mol}\right.$ photons $\left.\mathrm{m}^{-2} \mathrm{~s}^{-1}\right)$ and high light intensity $\left(110 \mu \mathrm{mol}\right.$ photons $\left.\mathrm{m}^{-2} \mathrm{~s}^{-1}\right)$

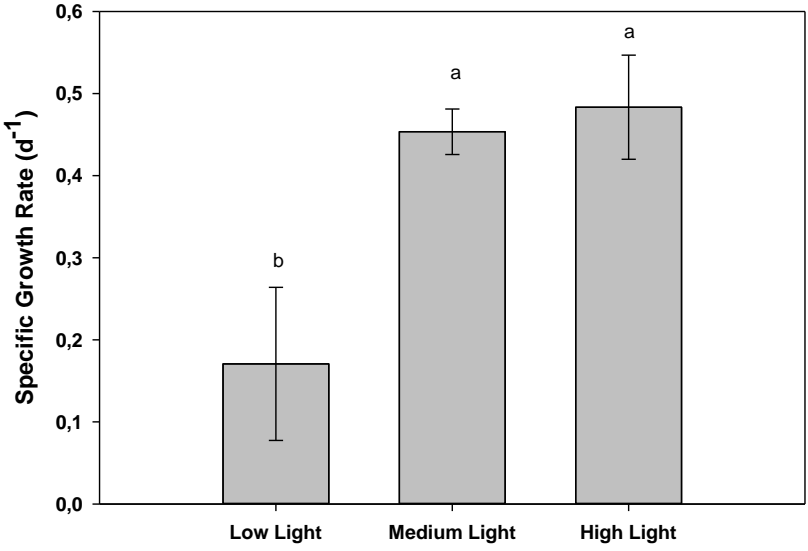

Figure 3. Specific growth rate $\left(\mathrm{d}^{-1}\right)$ of the Skeletonema sp. under different light intensity; Low light intensity $\left(28 \mu \mathrm{mol}\right.$ photons $\mathrm{m}^{-2}$ $\left.\mathrm{s}^{-1}\right)$, medium light intensity $\left(60 \mu \mathrm{mol}\right.$ photons $\left.\mathrm{m}^{-2} \mathrm{~s}^{-1}\right)$ and high light intensity $\left(110 \mu \mathrm{mol}\right.$ photons $\left.\mathrm{m}^{-2} \mathrm{~s}^{-1}\right)$. There was a significant difference in the SGR of the Skeletonema sp. under the different light intensities (One Way ANOVA, $\mathrm{p}=0.002$ ). Bars show the means $\pm \mathrm{SD}, \mathrm{n}=3$ 

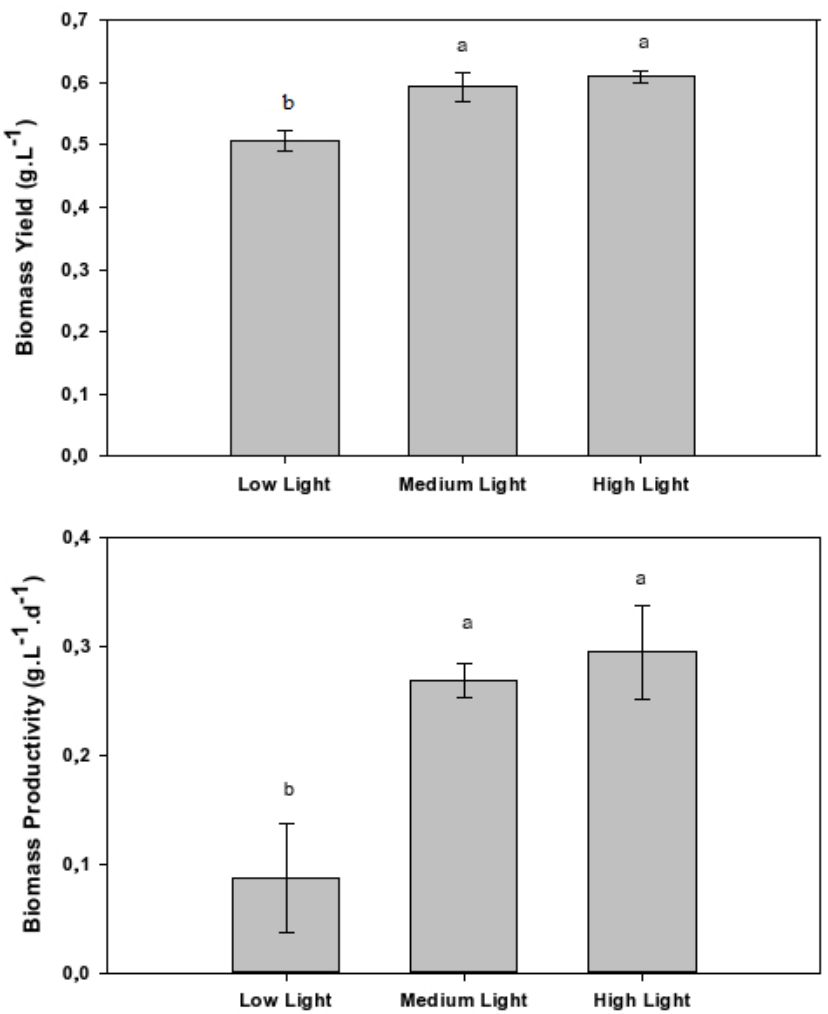

Figure 4. Biomass yield $\left(\mathrm{g} \mathrm{L}^{-1}\right)$ and biomass productivity $\left(\mathrm{g} \mathrm{L}^{-1} \mathrm{~d}\right.$ $\left.{ }^{1}\right)$ of the Skeletonema sp. under different light intensities; low light intensity $\left(28 \mu \mathrm{mol}\right.$ photons $\left.\mathrm{m}^{-2} \mathrm{~s}^{-1}\right)$, medium light intensity $\left(60 \mu \mathrm{mol}\right.$ photons $\left.\mathrm{m}^{-2} \mathrm{~s}^{-1}\right)$ and high light intensity $(110 \mu \mathrm{mol}$ photons $\left.\mathrm{m}^{-2} \mathrm{~s}^{-1}\right)$. There was a significant difference in the biomass yield (Fig. 4a) of the Skeletonema sp. under the different light intensities tested (One Way ANOVA, $\mathrm{p}=0.0250$ ). Also, a significant difference in biomass productivity (Fig. 4b) was observed between the light intensities (One Way ANOVA, $\mathrm{p}=0.001$ ). Bars show the means $\pm \mathrm{SD}, \mathrm{n}=3$

There was a significant difference in the biomass yield of the Skeletonema sp. under different light intensities (One Way ANOVA, $\mathrm{p}=0.0250)$. The highest biomass yield of the Skeletonema sp. was obtained at high light intensity $(0.60-$ $0.62 \mathrm{~g} \mathrm{~L}^{-1}$ ) and the lowest was obtained at low light intensity (0.49-0.52 $\mathrm{g} \mathrm{L}^{-1}$ ) (Figure 4.A). Similarly, there was a significant difference in biomass productivity between the light intensities (One Way ANOVA, $\mathrm{p}=0.001$ ). The highest biomass productivity of the Skeletonema sp. was achieved at high light intensity $\left(0.2952 \pm 0.0435 \mathrm{~g} \mathrm{~L}^{-1} \mathrm{~d}^{-}\right.$ $\left.{ }^{1}\right)$ and the lowest at low light intensity $\left(0.087 \pm 0.0499 \mathrm{~g} \mathrm{~L}^{-1}\right.$ $\mathrm{d}^{-1}$ ) (Figure 4.B).

The lipid yield and lipid content of the Skeletonema $\mathrm{sp}$. were not affected by the different light intensities tested (One Way ANOVA, $\mathrm{p}=0.054$ and $\mathrm{p}=0.193$, respectively). However, a significant difference in the lipid productivity was observed between the different light intensities (One Way ANOVA, $\mathrm{p}<0.001)$. The alga achieved its highest lipid productivity $\left(0.0661 \pm 0.007 \mathrm{~g} \mathrm{~L}^{-1} \mathrm{~d}^{-1}\right)$ when grown at medium light intensity and the lowest $\left(0.0124 \pm 0.005 \mathrm{~g} \mathrm{~L}^{-1}\right.$ $\mathrm{d}^{-1}$ ) was obtained at low light intensity (Figure 5).
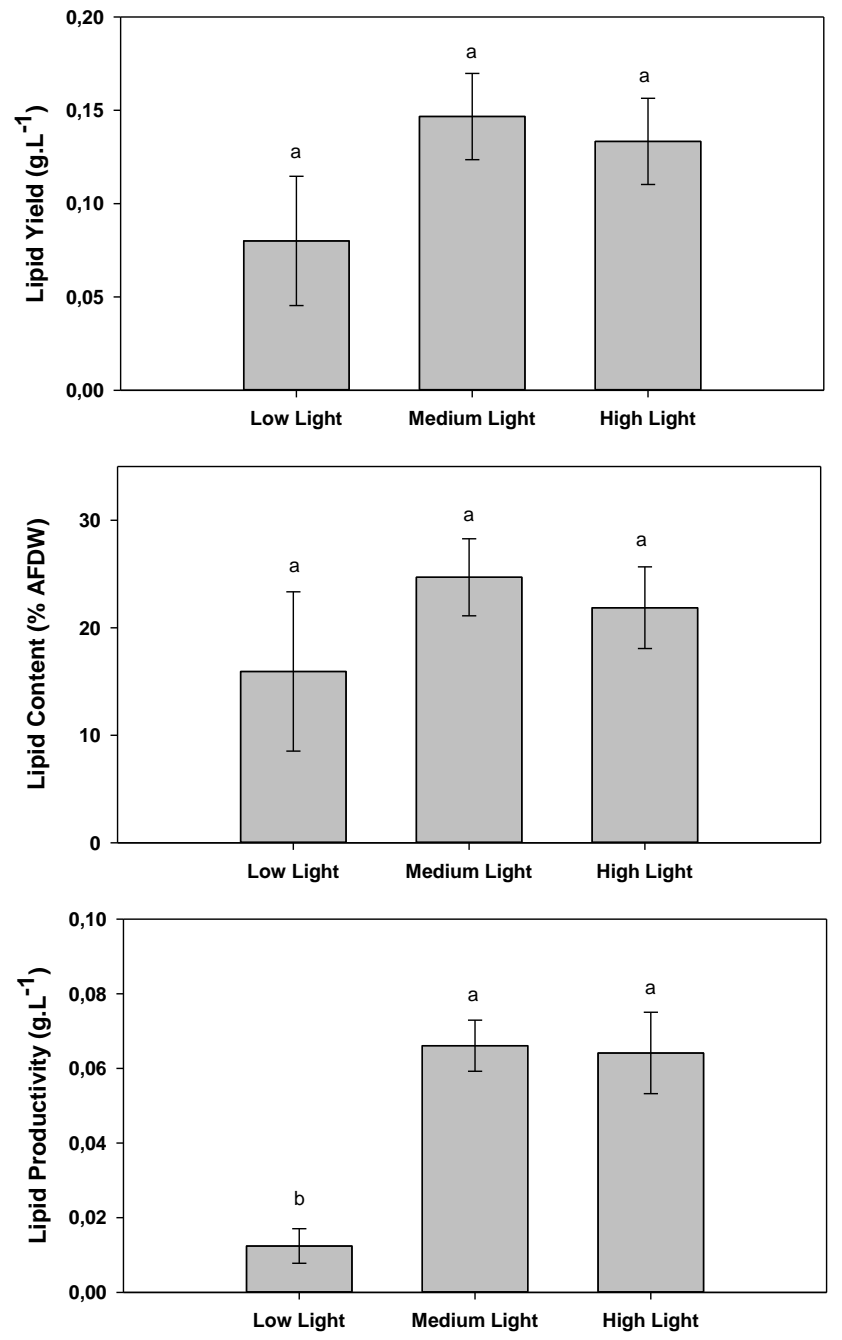

Figure 5. Lipid yield $\left(\mathrm{g} \mathrm{L}^{-1}\right)$, lipid content (\% AFDW) and lipid productivity $\left(\mathrm{g} \mathrm{L}^{-1} \mathrm{~d}^{-1}\right)$ of the Skeletonema $\mathrm{sp}$. under different light intensities; Low light intensity $\left(28 \mu \mathrm{mol}\right.$ photons $\left.\mathrm{m}^{-2} \mathrm{~s}^{-1}\right)$, medium light intensity $\left(60 \mu \mathrm{mol}\right.$ photons $\left.\mathrm{m}^{-2} \mathrm{~s}^{-1}\right)$ and high light intensity $\left(110 \mu \mathrm{mol}\right.$ photons $\left.\mathrm{m}^{-2} \mathrm{~s}^{-1}\right)$. There was no significant difference in the lipid yield (One Way ANOVA, p=0.054) and lipid content (One Way ANOVA, $\mathrm{p}=0.193$ ) of the Skeletonema $\mathrm{sp}$. under the different light intensities tested. However, a significant difference between light intensities was observed in the lipid productivity (One Way ANOVA, $\mathrm{p}<0.001$ ). Bars show the means $\pm \mathrm{SD}, \mathrm{n}=3$

\section{Discussion}

Growth rate, biomass and lipid productivities are important parameters in selecting microalgal species to be used as biodiesel feedstock. The ability to adapt and tolerate a wide range of environmental changes is another important criteria to consider for mass cultivation and biomass production of microalgae (Dębowski et al. 2012). When considering the mass production of microalgal biomass in outdoor open pond systems for any commercial application especially for biodiesel, the microalgae species should have the ability to adapt and tolerate a wide range of environmental changes encountered outdoors. Light intensity is one of these factors. In outdoor pond systems, 
light intensity fluctuates during the day and between seasons and is one of the key environmental parameters affecting the growth and storage products of microalgae (Ruangsomboon 2012). In this study, we found that the specific growth rate of the Skeletonema sp.UHO29 increased linearly with light intensity with the highest specific growth rate of $0.555 \mathrm{~d}^{-1}$ achieved at high light intensity $\left(110 \mu \mathrm{mol}\right.$ photons $\left.\mathrm{m}^{-2} \mathrm{~s}^{-1}\right)$ and the lowest $(0.109$ $\left.\mathrm{d}^{-1}\right)$ obtained at the lowest light intensity $(28 \mu \mathrm{mol}$ photons $\mathrm{m}^{-2} \mathrm{~s}^{-1}$ ). The results of this study are comparable to other studies. For example, Kitaya et. al. (2005) investigated the effects of six different light intensities from 20 to $200 \mu \mathrm{mol}$ photons $\mathrm{m}^{-2} \mathrm{~s}^{-1} \mathrm{on}$ cellular multiplication of microalga Euglena gracilis. They found that the highest multiplication rate of the microalgae cells was at a light flux of about $100 \mu \mathrm{mol}$ photons $\mathrm{m}^{-2} \mathrm{~s}^{-1}$. Difusa et al. (2015) studied the influence of different light intensities (27, 40.5, $54,67.5,81$ and $94.5 \mu$ mol photons $\mathrm{m}^{-2} \mathrm{~s}^{-1}$ ) on the growth and lipid production of Scenedesmus species ADIITEC-II and GUBIOTJT116 and found that both species achieved highest specific growth rate and biomass yield at light intensity of $81 \mu \mathrm{mol}$ photons $\mathrm{m}^{-2} \mathrm{~s}^{-1}$, but the highest lipid production was achieved under $94.5 \mu \mathrm{mol}$ photons $\mathrm{m}^{-2} \mathrm{~s}^{-1}$. Sforza et al. (2014) investigated the effect of different light intensities ranging from 10 to $1000 \mu \mathrm{mol} \mathrm{m} \mathrm{m}^{-2} \mathrm{~s}^{-1}$ on the growth and lipid content of Scenedesmus obliquus and found that the species achieved its maximum growth rate at $150 \mu \mathrm{mol}$ photons $\mathrm{m}^{-2} \mathrm{~s}^{-1}$. In contrast, Jayakumar et al. (2015) studied the influence of four different light intensities on the growth of two diatom species (Amphora sp. and Gyrosigma sp.) and found that both species recorded the highest specific growth rates at a much lower light intensity of about $40 \mu \mathrm{mol}$ photons $\mathrm{m}^{-2} \mathrm{~s}^{-1}$ with SGR of $0.2860 \mathrm{~d}^{-1}$ and $0.3067 \mathrm{~d}^{-1}$, respectively. Difference between algal species is not the only reason for the variation in specific growth rate but also differences between culture conditions, specifically the wide range of light intensities tested. Although the specific growth rate of the Skeletonema sp.UHO29 increases with increasing light intensity, with the highest SGR value obtained at $110 \mu \mathrm{mol}$ photons $\mathrm{m}^{-2} \mathrm{~s}^{-1}$, it does not mean that this particular light intensity is the optimum light intensity for the growth of the Skeletonema sp. Further studies i.e at a much higher light intensity and in outdoor culture trials are needed to find out the light intensity tolerance of the Skeletonema sp., especially if this alga is going to be developed in outdoor culture systems where irradiance can reach up to 2000 $\mu$ mol. photon $\mathrm{m}^{-2} \mathrm{~s}^{-1}$ on hot sunny days. Both biomass yields and specific growth rates of Skeletonema sp. were highest in the high light intensity treatment, resulting in the highest biomass productivity. This is because biomass productivity is a function of both biomass yield and specific growth rate.

Lipids are the main storage compound of diatoms $(\mathrm{Hu}$ et al. 2008; Mangas-Sanchez and Adlercreutz 2015) with average lipid content of about $25 \%$ of dry weight (Levitan et al. 2014). The highest lipid content of the Skeletonema sp.UHO29 found in our study was about $28.78 \%$ AFDW and this is comparable with other studies. For example, Sharmin et al. (2016) reported the highest lipid content of
Skeletonema costatum isolated from a Bangladesh coast of about $15.37 \%$. Laurenco et al. (2002) also reported lipid content of $S$. costatum ranging from 11.8 to $13.1 \%$ dry weight. However, the lipid content of $S$. costatum reported by Chen (2012) was much higher, ranging from 36.90 to $41.42 \%$ dry weight.

In this study, we found that the lipid yield and lipid content of Skeletonema sp.UHO29 under different light intensities showed no significant differences. This is in line with the study done by Cheirsilp and Torpee (2012) and Simionato et al. (2011) who found that light excess does not induce overproduction of lipids in Nannochloropsis, suggesting that our finding is not species-specific. Breuer et al. (2013) also found that the TAG content in Scenedesmus was independent of light intensity but strongly affected by other factors such as $\mathrm{pH}$ and temperature. Although there was no significant difference in lipid yield and the lipid content of the Skeletonema sp.UHO29 under the different light intensities tested in our study, the lipid productivity was significantly higher at medium and high light intensity than at low intensity. Lipid productivity is a function of the growth rate and the lipid yield, and therefore high growth rate and lipid yield will result in high lipid productivity. The maximum lipid productivity of the Skeletonema sp.UHO29 in this study was about $0.066 \mathrm{~g} \mathrm{~L}^{-1} \mathrm{~d}^{-1}\left(66 \mathrm{mg} \mathrm{L}^{-1} \mathrm{~d}^{-1}\right)$ and this lipid productivity is higher in comparison with other diatoms' lipid productivity. For example, the marine diatom Gyrosigma sp. has average lipid productivity of $24.1 \pm 0.2$ $\mathrm{mg} \mathrm{L}^{-1} \mathrm{~d}^{-1}$ (Govindan et al. 2019). Skeletonema marinoi CCMP 2092 and CCMP 2052 have lipid productivities of $0.85 \pm 0.02 \mathrm{mg} \mathrm{L}^{-1} \mathrm{~d}^{-1}$ and $0.66 \pm 0.03 \mathrm{mg} \mathrm{L}^{-1} . \mathrm{d}^{-1}$, respectively (d'Ippolito et al. 2015). The halophilic diatom, Amphora sp.MUR258, has the highest lipid productivity of about 41 $\mathrm{mg} \mathrm{L}^{-1} \mathrm{~d}^{-1}$ (Indrayani 2017).

In conclusion, we found that Skeletonema sp.UHO29 prefers high light intensity for optimum growth but medium-light for higher lipid production. The highest growth rate and biomass productivity were obtained at the highest light intensity $\left(110 \mu \mathrm{mol}\right.$ photons $\left.\mathrm{m}^{-2} \mathrm{~s}^{-1}\right)$ but the highest lipid productivity was achieved at medium light intensity $\left(60 \mu \mathrm{mol}\right.$ photons $\left.\mathrm{m}^{-2} \mathrm{~s}^{-1}\right)$. The present study suggests that Skeletonema sp.UHO29 is suitable for mass cultivation in outdoor open pond systems i.e raceway ponds, because of its ability to grow well at high light intensity. It is a promising microalgal species for use as a biodiesel feedstock due to its high growth rate, high lipid content and lipid productivity.

\section{ACKNOWLEDGEMENTS}

The authors wish to thank the Ministry of Research and Technology and Higher Education of Republic Indonesia for funding the research through the Applied Research Scheme in 2019 (Contract No: 519/UN29.20/PPM/2019). The authors declare that they have no conflict of interest. 


\section{REFERENCES}

Ahmad AL, Mat Yasin NH, Derek CJC, Lim JK. 2011. Microalgae as a sustainable energy source for biodiesel production: A review. Renew Sustain Energ Rev 15: 584-593

Al-Qasmi M, Raut N, Talebi S, Al-Rajhi S, Tahir Al-Barwani T. 2012. A review of effect of light on microalgae growth. Proceedings of the World Congress on Engineering Vol I. WCE, London, UK, 4-6 July 2012.

Andersen RA, Kawachi M. 2005. Traditional microalgae isolation techniques. In: Anderson RA (eds) Algal Culturing Techniques. Elsevier. Amsterdam.

Bligh EG, Dyer WJ. 1959. A rapid method of total lipid extraction and purification. Can J Biochem Physiol 37: 911-917.

Borowitzka MA, Moheimani NR. 2013. Sustainable biofuels from algae. Mitig Adapt Strat Glob Change 18: 13-25.

Borowitzka MA. 2016. Algal physiology and large-scale outdoor cultures of microalgae. In: Borowitzka MA, Beardall J, Raven JA (eds) The Physiology of Microalgae. Springer, Dordrecht.

Breuer G, Lamers PP, Martens DE, Draaisma RB, Wijffels RH. 2013. Effect of light intensity, $\mathrm{pH}$, and temperature on triacylglycero (TAG) accumulation induced by nitrogen starvation in Scenedesmus obliquus. Bioresour Technol 143: 1-9. DOI 10.1016/j.biortech.2013.05.105.

Cheirsilp B, Torpee S. 2012. Enhanced growth and lipid production of microalgae under mixotrophic culture condition: Effect of ligh intensity, glucose concentration and fed-batch cultivation. Bioresour Technol 110: 510-516

Chen YC. 2012. The biomass and total lipid content and composition of twelve species of marine diatoms cultured under various environments. Food Chem 131: 211-219.

Chisti Y. 2007. Biodiesel from microalgae. Biotechnol Adv 25 (3): 294 306.

d'Ippolito G, Sardo A, Paris D, Vella FM, Adelfi MG, Botte P, Gallo C, Fontana A. 2015. Potential of lipid metabolism in marine diatoms for biofuel production. Biotechnol Biofuels. DOI 10.1186/s13068-0150212-4

Dębowski M, Zieliński M, Krzemieniewski M, Dudek M, Grala A. 2012. Microalgae cultivation methods. Pol J Nat Sci 27 (2): 151-164.

Difusa A, Talukdar J, Kalita MC, Mohanty K, Goud VV. 2015. Effect of light intensity and $\mathrm{pH}$ condition on the growth, biomass and lipid content of microalgae Scenedesmus species. Biofuels 6 (1-2): 37-44.

Govindan N, Maniam GP, Yusoff MM, Rahim MHA, Chatsungnoen T, Ramaraj R, Chisti Y. 2019. Statistical optimization of lipid production by the diatom Gyrosigma sp. grown in industrial wastewater. J Appl Phycol. DOI: 10.1007/s10811-019-01971-x

Guillard RR, Ryther JH. 1962. Studies of marine planktonic diatoms. 1. Cyclotella chui Hustedt, and Detonula confervacea (Cleve). Can J Microbiol 8: 229-239.

Hu Q, Sommerfeld M, Jarvis E, Ghirardi M, Posewitz M, Seibert M, Darzins A. 2008. Microalgal triacylglycerols as feedstocks for biofuel production: perspectives and advances. Plant J 54: 621-639.

Indrayani I, Haslianti, Asriyana. 2018. Isolation and screening of marine microalgae from Kendari waters, Southeast Sulawesi, Indonesia suitable for outdoor mass cultivation in hypersaline media. AACL Bioflux 11 (5): 1445-1455.

Indrayani I, Moheimani NR, Borowitzka MA. 2019. Long-term reliable culture of a halophilic diatom, Amphora sp. MUR258, in outdoor raceway ponds. J Appl Phycol 31: 2771-2778.

Indrayani I, Moheimani, NR, de Boer K, Bahri PA, Borowitzka, MA 2020. Temperature and salinity effects on growth and fatty acid composition of a halophilic diatom, Amphora sp. MUR258 (Bacillariophyceae). J Appl Phycol 31 (5), 2771-2778.

Indrayani I. 2017. Isolation and Characterization of Microalgae with Commercial Potential. [Dissertation]. Murdoch University, Perth, Western Australia.

Jayakumar S, Peng LY, Rahim MHA, Maniam GP, Govindan N. 2015. Studies about the effect of different photosynthetic light intensity on two isolated species of marine microalgae (diatom) for high lipid production. Adv Environ Biol 9 (27): 332-340

Kates M, Volcani BE. 1966. Lipid components of diatoms. Biochim Biophys Acta 116: 264-278.
Khatoon H, Banerjee S, Yusoff FM, Shariff M. 2010. Effects of salinity on the growth and proximate composition of selected tropical marine periphytic diatoms and cyanobacteria. Aquac Res 41: 1348-1355.

Kitaya Y, Azuma H, Kiyota M. 2005. Effects of temperature, $\mathrm{CO}_{2} / \mathrm{O}_{2}$ concentrations and light intensity on cellular multiplication of microalgae, Euglena gracilis. Adv Space Res 35 (9): 1584-1588.

Laurenco SO, Barbarino E, Manchini-Filho J, Schinke KP, Aidar E. 2002. Effects of different nitrogen sources on the growth and biochemical profile of 10 microalgae in batch culture: an evaluation for aquaculture. Phycologia 41 (2): 158-168.

Levitan O, Dinamarca J, Hochman G, Falkowski PG. 2014. Diatoms: a fossil fuel of the future. Trends Biotechnol 32: 117-124.

Mangas-Sanchez J, Adlercreutz P. 2015. Highly efficient enzymatic biodiesel production promoted by particle-induced demulsification. Biotechnol. Biofuels 8: 58. DOI: 10.1186/s13068-015-0247-6

Masojídek J, Torzillo G, Koblizek M. 2013. Photosynthesis in microalgae. In: Richmond A, Hu Q (eds) Handbook of Microalgal Culture: Applied Phycology and Biotechnology. 2nd ed. John Wiley \& Sons, Chichester, UK

Mata TM, Martins AA, Caetano NS. 2010. Microalgae for biodiesel production and other applications: A review. Renew Sustain Energ Rev 14 (1): 217-232

Mercz TI. 1994. A study of high lipid yielding microalgae with potential for large-scale production of lipids and polyunsaturated fatty acids. [Dissertation]. Murdoch University, Perth, Western Australia.

Moheimani NR, Borowitzka MA, Isdepsky A, Fon Sing S. 2013. Standard methods for measuring growth of algae and their composition. In: Borowitzka MA, Moheimani NR (eds.) Algae for Biofuels and Energy. Springer, Dordrecht.

Pal D, Khozin-Goldberg I, Cohen Z, Boussiba S. 2011. The effect of light, salinity, and nitrogen availability on lipid production by Nannochloropsis sp. Appl Microbiol Biotechnol 90: 1429-1441.

Pal SW, Singh NK, Azam K. 2013. Evaluation of relationship between light intensity (Lux) and growth of Chaetoceros muelleri. Oceanography 1 (3): 1-4.

Parmar A, Singh NK, Pandey A, Gnansounou E, Madamwar D. 2011. Cyanobacteria and microalgae: a positive prospect for biofuels. Bioresour Technol 102: 10163-10172.

Popovich CA, Damiani C, Constenla D, Leonardi PI. 2012. Lipid quality of the diatoms Skeletonema costatum and Navicula gregaria from the South Atlantic Coast (Argentina): evaluation of its suitability as biodiesel feedstock. J Appl Phycol 24: 1-10.

Pulz O, Scheinbenbogen K. 1998. Photobioreactors: design and performance with respect to light energy input. Adv Biochem Eng Biot 59: 123-152.

Rodolfi L, Zittelli GC, Bassi N, Padovani G, Biondi N, Bonini G, Tredici MR. 2009. Microalgae for oil: Strain selection, induction of lipid synthesis and outdoor mass cultivation in a low-cost photobioreactor. Biotech Bioeng 102 (1): 100-112.

Ruangsomboon S. 2012. Effect of light, nutrient, cultivation time and salinity on lipid production of newly isolated strain of the green microalga, Botryococcus braunii KMITL 2. Bioresour Technol 109: 261-265.

Sforza E, Gris B, De Farias Silva CE, Morosinotto T, Bertucco A. 2014 Effects of light on cultivation of Scenedesmus obliquus in batch and continuous flat plate photobioreactor. Chem Eng Trans 38: 211-216.

Sharmin T, Md Chowdhury, Hasan M, Aftabuddin S, Rahman Md.A, Khan M. 2016. Growth, fatty acid, and lipid composition of marine microalgae Skeletonema costatum available in Bangladesh coast: consideration as biodiesel feedstock. J Mar Sci. DOI: $10.1155 / 2016 / 6832847$

Simionato D, Sforza E, Carpinelli EC, Bertucco A, Giacometti GM, Morosinotto T. 2011. Acclimation of Nannochloropsis gaditana to different illumination regimes: effects on lipids accumulation. Bioresour Technol 102: 6026-6032

Wang Y, Liu S, Tian X, Fu Y, Jiang X, Li Y, Wang G. 2018. Influence of light intensity on chloroplast development and pigment accumulation in the wild-type and etiolated mutant plants of Anthurium andraeanum 'Sonate'. Plant Signal Behav 13 (8): e1482174. DOI: 10.1080/15592324.2018.1482174 